\title{
'Lived experiences' of the love of God according to 1 John 4: A spirituality of love
}

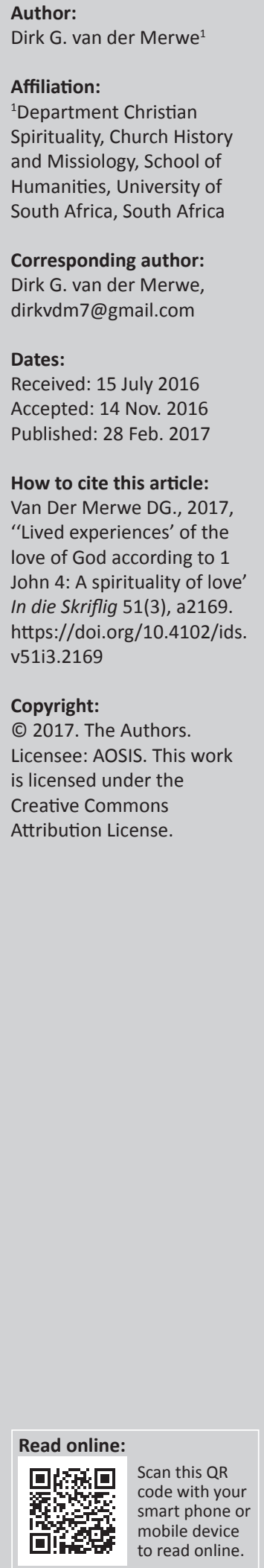

This article probes to enlighten this old truth of the revelation and experience of God's love in a fresh, dynamic and different way, from the perspective of early Christian spirituality. How did the early Christians possibly experience the love of God existentially in their daily lives? Another question is, 'What did they experience when they have read this text of 1 John 4:7-21? This article looks briefly at how the author of 1 John understands the character of God which is necessary for understanding the love of God. The article continues to express how the 'love' of God (according to $1 \mathrm{Jn}$ ), was experienced by the Early Church through the following modes of lived faith experiences that emerged from the text and existential life situations: faith experience, relational experience and mystical experience. The article shows how the contemplative reading of sacred texts can contribute to a deeper understanding and lived faith experience of God.

\section{Introduction}

1 John 4 twice states explicitly and apophatically $(4: 12,20)^{1}$ that nobody has ever seen God, but simultaneously concedes that God can existentially be experienced (and be seen), because he revealed himself in Jesus Christ (4:9-10) and because he lives in believers (4:15). This dichotomy of seeing or not seeing God also occurs in both the Old and New Testaments and occurs in particular in the corpus Johanneum ${ }^{2}$ (cf. Jn 1:18; 4:12; 5:37; 6:46; 14:8-11; 1 Jn 4:12, 20). These two apophatic statements were purposefully mentioned by the author ${ }^{3}$ in this particular context where love figures prominently. With this combination the Elder wants to prove something. The rhetoric embedded in 4:12, 20 (cf. also 4:9, 10,14) explains how the seeing or experiencing of God occurs in and through the lives of God's children. It happens through his revelations of his love (himself) in the lives of his children. This article investigates the spirituality of God's love; the 'lived faith experiences' of God in the experience of his love ${ }^{5}$ from various perspectives.

The approach in this article is deductive. An exegetical analysis of verses 7-21 will be conducted. This text is probably the most important text in the New Testament that explains God's love the best. The article starts to point out the peculiarities of the pericope to legitimise this research and chosen subject. Then it investigates briefly how the Elder portrays the character of God in 1 John. The third and largest part investigates how the children of God had and can have lived faith experiences of the 'love of God', which I want to phrase, a spirituality of love. This will be conducted investigating the following modes of lived experiences that emerge from the text: a

1.All references to 1 John will be indicated only by chapters and verses.

2.It is a privilege to dedicate this research to Jan van der Watt who was my supervisor in my doctoral studies. He was the person who formed my Johannine research and influenced me to fall in love with the corpus Johanneum. One thing that I respect him for is that, in spite of serious critical thinking, he still remained a devoted believer. He set an example for his students with regard to his work ethics, his theology, methodology and hermeneutics. Due to his encompassing interest in the lives of his students he always had time for a good academic conversation. I want to thank him sincerely, as many others would, for what he meant to me and contributed to the formation of my theological development. I am proud to be associated with an outstanding scholar as Jan van der Watt. Lastly, I also want to thank him sincerely for what he did for the church and theological education in South Africa. It is always a pleasure to read his innovative publications.

3. Hereafter refer to as Elder.

4.According to Scholer (1990:309) love is a dominant theme in 1 John which he regards as a 'powerful theological essay'.

5.Due to the reading of the text from a spirituality perspective and due to the plethora of definitions of Spirituality, I would like to define Spirituality as to be used in this document. I want to look briefly at the notion of 'spirituality' in consulting the works of three most influential scholars in this field. Philip Sheldrake (2000:40) defines (Christian) spirituality as 'a conscious relationship with God, in Jesus Christ, through the indwelling of the Spirit and in the context of the community of believers'. Sandra Schneiders (2000:254) defines Christ, through the indwelling of the Spirit and in the context of the community of believers'. Sandra Schneiders $(2000: 254)$ defines
spirituality as 'the experience of consciously striving to integrate one's life, in terms not of isolation and self-absorption, but of selfspirituality as 'the experience of consciously striving to integrate one's life, in terms not of isolation and self-absorption, but of self-
transcendence toward the ultimate value one perceives'. Spirituality, then, as a lived experience, is by definition 'determined by the particular ultimate value, within the horizon of which the life project is pursued'. In 2002 Kees Waaijman (2002:312) defined spirituality as 'the divine-human relational process of transformation'. This brief definition of Waaijman can be divided into: the 'divine-human relationship' and a 'relationship of transformation'. With his definition of spirituality Waaijman lays a hand on the core of human existence, namely the believer's relationship to God (Van der Merwe 2015:1).

For this article a combination of the above and other related complementary definitions have been opted for. Spirituality, as used in this article, refers to 'living a life of transformation and self-transcendence that resonates with the lived experiences of the divine'. This definition consists of two aspects: 'a lived faith experience of the divine-human relationship' and 'living a life of transformation and self-transcendence that resonates with that of the divine-human relationship' (Van der Merwe 2015:1). 
faith experience of God's love, a relational experience of God's love, and a mystical experience of God's love.

\section{Peculiarities in the text (4:7-21)}

Characteristic in 1 John is the dialectic language that occurs throughout the epistle and the cyclic reasoning with regard to themes such as eschatology, love, commandments, sin, antichrist, revelation, fellowship, et cetera. Both these features (dialectic language and cyclic reasoning) occur in the selected text.

In this pericope (4:7-21), a high frequency of other text peculiarities also occur. The recognition of these peculiarities, on their own, creates spiritualties in the reading of the text. Only in this short pericope (4:7-21), in comparison with the rest of 1 John, there are three references to 'God (Father) who sent ( $\dot{\alpha} \pi \circ \tau \tau \varepsilon ́ \lambda \lambda \omega)$ his Son' $(4: 9,10,14$; implied in 3:9); two references to the explicit and apophatic expressions that 'No one has ever seen God' or 'God whom they have not seen'. The verb $\tau \varepsilon \lambda \varepsilon$ เó $\omega$ [perfected] has been used only five times in 1 John of which four $(4: 12,17,18$; adjective in 4:18) occur in this pericope regarding the perfection of love, and the other one in 2:5.

References to 'love' occur in the epistle in 2:5, 10, 15(3x), 3:1, $10,11-23(7 x), 4: 7-21(27 x), 5: 1,2$ (bis), 3(4x). This indicates that the highest frequency of occurrence of reference to love occurs in 4:7-21. In this pericope believers are also addressed as 'Beloved' ('A $\gamma \alpha \pi \eta \tau o$ í). This adjective occurs six times in 1 John of which two occurrences are in 4:7-21. Then references to 'God' are also the highest in this pericope in comparison with the rest of the Epistle. The only reference of the Father (4:14) as the one who sent his Son as the Saviour of the world occurs in this pericope. The noun 'God' is used 20 times in this pericope of 15 verses which is saturated by the concept of 'love' (27x). Love is an active part of the household of God where God features as Father. Four possible reasons can be offered: first, because God as deity is ontologically identified as 'love' (4:8); second, God's love is here connected with the incarnation or salvation (4:9); third, through love this God dwells in believers; and fourth, through love this God is revealed (4:10).

\section{The Elder's Depiction of God Character of God in 4:7-21}

The noun $\theta$ sò $\varsigma$ [God] occurs 20 times and the genitive

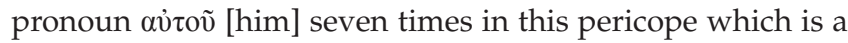
high frequency of occurrence in such a small pericope. This high frequency occurs only here in the corpus Johanneum. This high frequency of occurrences of both God (27x) and love (27x) is not accidental. These two words are very closely linked in this pericope. Everything said about love revolves around God and everything said about God revolves around love. God is also referred to once as Father (Father connected to family love). He is portrayed to be the head of the family. He loves his children whom are born from him.
In this pericope the two most important aspects communicated about God are, 'No one has seen God' (4:12, $20)$ and 'God is love' $(4: 8,16)$. The latter one (love) implies 'God sending his Son'.

\section{No one has seen God $(4: 12,20)$}

In this pericope both apophatic and kataphatic language occur. God is twice referred to be not seen, 'No one has ever seen God' (4:12); 'God whom they have not seen' (4:20). A literal translation of $4: 12$ is, 'God no one has ever seen'. God is the object in this verse and therefore he is placed first. The emphasis is on God (Painter 2002:271). Smalley (1989:246) interprets the order of these words as deliberate. The noun God ( $\theta \varepsilon$ ćs) without the article has been used by the Elder to provide the following absolute meaning:

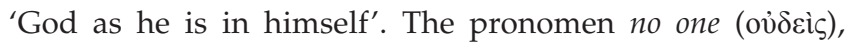
immediately after 'God', then has the meaning of 'God in himself no one has ever seen'. For Smalley (1989:247) the Elder has good reason for making this point now. In opposition to this declaration the Elder declares that he can be discerned - through the practise of love which he himself arouses (4:12b). Thus, the contrast in 4:12 explains phenomenologically and existentially that:

no one has ever seen God; yet God can dwell in his children, and the sign and reality of this is to be found in their love for one another, and consequently for him. (Smalley 1989:247)

The denial here is to make clear that the only way of seeing God was in (concerning content) and through (instrumental) the revelation of the Son. This is the idea in John 14:8-11 and 1 John 4:7-12, 14. The love of the Father is made known in the 'Son' (Painter 2002:271). For the Elder the alternative to see God is 'if we love one another' ('if we love one another, God lives in us' $-4: 12)^{7}$

\section{God is love}

The author of the Gospel of John has already stated that 'God is Spirit' (Jn 4:24) and the Elder that 'God is light' (1:5), 'God is faithful and just' (1:9) and 'He is righteous' (2:29). Now the Elder gives one more embracing statement concerning the

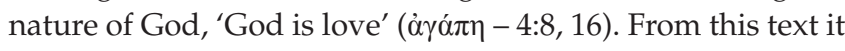
becomes evident that to have a: 'lived experience' of the love of God is to manifest His love in the believer's own life. Without manifesting God's love in the believer's own life, such a person cannot know God or ever have known the love of God (Akin 2001:178) or experience His presence.

According to Smalley (1989:239-40), the Elder's reference to God who is love, should be understood from the background of the Old Testament. The Old Testament portrays God as 'living, personal and active' ${ }^{8}$ This is contrary to 'the Greek concept of deity which was abstract in character'

7.Discerning God is more than the practice of love in 4:7-12. Moreover, it is more likely that the Elder regarded love in the most absolute sense.

8.In the Torah (which influenced Johannine thought) it is noted how Israel experienced God's love (provision and protection) during the Exodus from Egypt, provision of food and water in the desert, and protection against Israel's enemies. 
(Akin 2001:178). The controlling principle in this text is that God, who is the source of love, Himself loves $(4: 7,10,19)$. The preposition from $(\dot{\varepsilon} \kappa)$ from the phrase because love flows

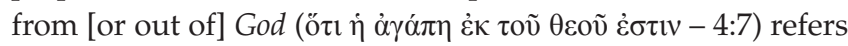
to God as the source (Akin 2001:178). In 4:7 this is verified in the ötr-clause. He first loved his children $(4: 10,19)$ and the Elder states that he loves them so much (4:11). God communicates his love through sending His only Son (4:9). To love should also be true of those who have been born of God (4:7). His love is not an abstract concept; it is a concrete action, thus an experience.

\section{The Elder's communication of love spirituality}

\section{The connectedness of love with other themes in the epistle}

\section{Chapter 2}

In 2:10, 15 the verb for love occurs three times and the noun once. In 2:10 the love of a brother and sister living in the light is the consequence of love, 'Whoever loves a brother or sister lives in the light'. The rest occur in 2:15. The believer is exhorted not to love the world. Love for the world ${ }^{9}$ is opposed to the love of the Father $(2: 15)$. Adherence to the apostolic message should be regarded seriously.

\section{Chapter 3}

This chapter revolves around the praise of love for one another. In 3:11-18 the verb occurs four times $(3: 11,14$ [2x], $18)$ and the noun twice $(3: 16,17)$. In $3: 23$ the verb $(\dot{\alpha} \gamma \alpha \pi \tilde{\omega} \mu \varepsilon v$, subjunctive) functions as an exhortation to 'love one another, just as he has commanded us'. Smalley (1989:264-65) points out that the exhortation for Christians to love, is both the result of what God has done for us in Christ (cf. vv. 9, 10, 14) and it is also commanded by him (cf. Brooke, 1912:127). Smalley (1989) indicates that:

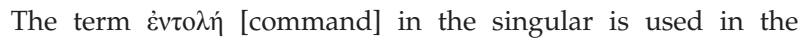
Johannine letters to refer to the one great commandment of love (cf. $2: 7-8 ; 3: 23 ; 2$ John 5-6). In the plural the same word is associated with the deeds which give concrete form to the love command itself (cf. 2:3-4; 3:22, 24; 5:2-3; 2 John 6). (pp. 264-265)

\section{Chapter 5}

Chapter 5 refers to a true believer as being a child of God who will not only love the Father, but also the Father's other children. The Elder uses the metaphor of a parent and child to explain this (5:1). In his further explanation of this, he changes the word order of what he has said in 4:20. The logic seems to be the reverse (Akin 2001:190). In both these verses, an interrelation occurs between the 'love of God' and the 'love of other'. The one strengthens the other (Akin 2001:191). Smalley (1989:268) asserts '... that each kind of love (for God,

9.The noun kóruoc is used here for the second time in $1 \mathrm{John}($ see 2.2$)$. It appears in the Johannine letters and Gospel with two basic meanings: 'the created universe or life on earth (cf. 3:17; 4:17; also John 1:10); and human society, temporarily controlled by the power of evil, organized in opposition to God (cf. 5:19; 4:3-5; also

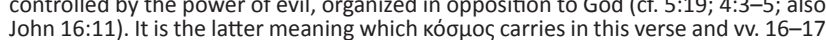
John 16:11). It is the latter meaning which kó $\sigma \mu$ os carries in this
(where the word occurs six times in all)' (Smalley 1989:81). and for others) demonstrates the genuineness of the other, and reinforces it (cf. 4:21)' (also Atkin 2001:191).

\section{The 'lived faith experiences' of the love of God from 4:7-21 A faith experience of God's love}

The first configuration of the spirituality of God's love can be explained from the perspective 'to believe that God has sent his Son as a Revealer and Savior'. The Elder believes that Jesus is the embodiment of the love of God. His portrayal of Jesus from three different perspectives $(4: 9,10,14)$ in this particular pericope (4:7-21) is to explain the phenomenology of God's love.

For the Father to reveal Himself and be involved in the salvation of mankind (to communicate his light ( $\varphi \omega \tau$ - 1:7), he had to send His Son into the world. The Elder begins this epistle referring to how Jesus was physically experienced by Himself and others. They have seen him, heard him touched him (Hiebert 1988:203). The Elder informs his readers and the

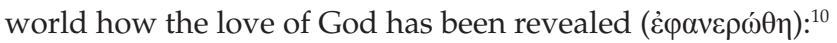

God's love was revealed among us in this way: God sent his only Son into the world so that we might live through him. ${ }^{10}$ In this is love, not that we loved God but that he loved us and sent his Son to be the atoning sacrifice for our sins' (4:9-10 - New Revised Standard Version [NRSV]; this relates to Jn 3:16).

An equivalent statement occurs also in $4: 14:{ }^{~}{ }^{14}$ And we have seen and do testify that the Father has sent his Son as the Savior of the world' (NRSV). A content comparison of these three verses indicates that they are similar in their reasoning:

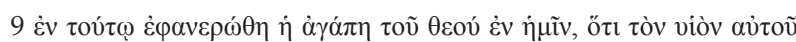

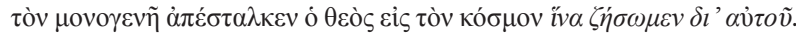

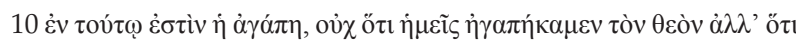
$\alpha$ $\dot{\alpha} \mu \alpha \rho \tau \imath \tilde{\omega} v \dot{\eta} \mu \tilde{\omega} v$.

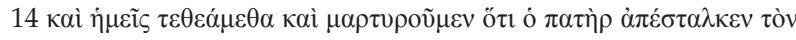

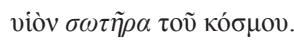

The phrase 'God's love was revealed among us in this way' (4:9) serves in this context as an introduction to the rest of the content of these three verses. Thus, these three verses describe the revelation of God's love for the world..$^{11}$ First, God's love has a salvific purpose: 'that we might live through him (iv $\alpha$

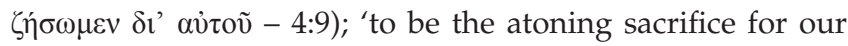

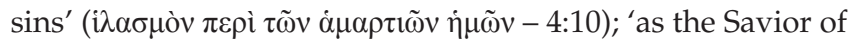

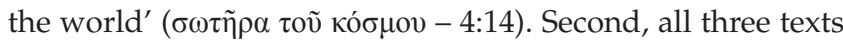
refer to God's initiative and salvific involvement (cf. Dodd 1946:110ff.): 'God' ( $\theta \varepsilon$ ov - 4:9); 'God' ( $\theta$ còv - 4:10); 'the Father'

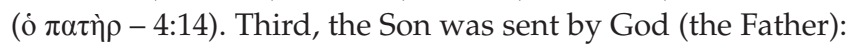
'God sent' ( $\alpha \pi \varepsilon \dot{\varepsilon} \sigma \alpha \lambda \kappa \varepsilon v$ ó $\theta \varepsilon \dot{s} \varsigma$ - 4:9); 'he loved us and sent'

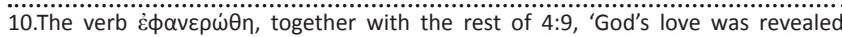
among us in this way: God sent his only Son into the world so that we might live through him', refer to the incarnation reflected and discussed in 1:1-3.

11.Rensberger (2006:286) is correct in his reference that it is the 'divine Christ and Son of God $(2: 22-24 ; 3: 23 ; 4: 2,14-15 ; 5: 1,5,9-12 ; 2$ John $3,7,9)$ ' in-the-flesh and his death that reveal the love of God. This forms the example for those who follow him (3:16-18; 4:9-11). This revelation in Jesus Christ reveals the love of God and also makes this love available to the 'children of God'. 


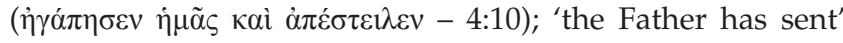
(ó $\pi \alpha \tau \eta \dot{\rho} \dot{\alpha} \pi \dot{\varepsilon} \sigma \tau \alpha \lambda \kappa \varepsilon v, 4: 14$ ). Fourth, the saving act of Jesus involved: 'that we might live through him' (iv $\alpha \eta j \sigma \omega \mu \varepsilon v \delta$ '

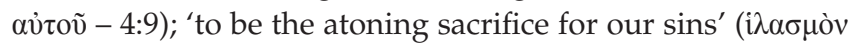
$\pi \varepsilon \rho \grave{i} \tau \tilde{\omega} v \dot{\alpha} \mu \alpha \rho \tau(\tilde{\omega} v \dot{\eta} \mu \tilde{\omega} v-4: 10)$; 'the Saviour of the world'

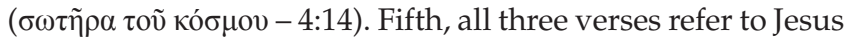
in different ways: 'his only Son' (

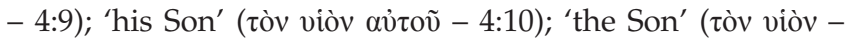
4:14) (cf. Van der Merwe 2005:445ff.). For Jones (2010:185) the acceptance (believe) of the sending of the Son is in effect to accept (the lived faith experience of) the Father's love (4:9). ${ }^{12}$

The content of these three texts complement each other. ${ }^{13}$ It describes the 'love of God' (salvation of the world) from different perspectives. For believers (children of God) their initial salvation, continual change and transformation should be an experience of God's love for them. This asks for a specific mind-set to make them aware of this. If not, the believer will fail to experience this salvific love of God.

In this pericope 'love' is a synonym for 'life'. To 'love' is to 'live'. To experience 'the love of God' is to experience 'the life (eternal life) of God', the life that is in God (see Jn 5:26 - 'the Father has life in himself ... the Son also to have life in himself'). To accept the sending of the Son is in effect to accept the Father's love (4:9; Jones 2010:185). The 'experience' of life, is a 'lived faith experience' of God's love. ${ }^{14}$ In the Gospel of John 'born from above/the Spirit' is linked with life $(3: 3,5)$. In 1 John 'born from God' is connected with love (4:7). Through 'knowledge' and 'faith' these believers experienced in their relationship with the resurrected Christ the costliness (only Son) of the love of God, the foundation (his Son) of the love of God, the content (Saviour) of the love of God and finally the physical existential reality of the love (Jesus). This identification of Jesus reflects on the ontology (nature or being) of God and the new life in Christ (cf. Schwöbel 1998).

When the Elder refers the third time to God sending his Son (4:14), he refers to God intimately as Father. With this use of 'Father' he makes the salvific event a more intimate personal experience of God's love (a Father's love). He uses the emphatic 'we' (ं $\mu \varepsilon i \varsigma)^{15}$ and testifies that their message is embedded in historical reality and personal lived faith experiences. They testify about the Father's saving activity in the Son. This recalls the content of the Epistle's prologue itself (1:1-3) and connects 1:1-3 with 4:9-14. This affirms clearly the mission of the incarnate Christ. The Elder wants to emphasise that although 'no one has

12.Scholer (1990:309) is of the opinion that, according to 1 John, a person can only obtain true membership in the community when: '(1) believing in the name of God's Son Jesus Christ (see 1 John $3: 23 ; 5: 1,5,10,13$ ) or confessing that Jesus is the Christ, the Son of God (see 1 John 2:22-23; 4:2-3,15); and (2) loving one anothe (see 1 John $3: 11 ; 3: 23 ; 4: 7,11-12,20-21$ )'. The two prerequisites are also used together in 3:23.

13.Verses 9 and 10 are closer to each other than to 14 , because of their wording

14.This reality and manifestation of God's love is experienced through the transformative existential encounter with the resurrected Christ. The Early Church readers came to a further spiritual experience of him. Now they experience him as God's 'Only Son', 'Son of God', 'Son as the Saviour' and 'Jesus'. These lived God's 'Only Son', 'Son of God', 'Son as the Saviour' and 'Jesus'. These lived
experiences let them experience the divine, the new life in God (cf. 4:9, 13, 16) and experiences let them experience the divine, the new life in God (cf. 4:9, 13, 16) and
his love. The testimony of the Elder is about this new life and love. The Elder wants the readers to share this with him.

15.The personal pronoun $\eta \mu \varepsilon i \bar{\varsigma}$ precedes the verb, $\tau \varepsilon \theta \varepsilon \alpha \dot{\alpha} \mu \varepsilon \theta \alpha$ at the beginning of $4: 14$ seen God', 'we have' seen and existentially experience him through his Son whom he sent (cf. Akin 2001:183). ${ }^{16}$

In the very next verse (4:15 - 'If anyone acknowledges that Jesus is the Son of God, God lives in him and he in God') the content of this confession is extended. It confirms communion between God and the person making the statement. It is a confession of public conviction and acknowledgment that reveals an inward commitment:

Jesus is the Son of God. I believe in him. ${ }^{17}$ I trust in him not just as the Savior of the world, but as my Savior. I personally trust in him as the Savior, the Son sent from God.' Again the Elder confirms the mutual abidance of, 'God lives in him and he in God. (cf. Marshall 1978:220)

This confession proves to be the result of receiving new life resulting in a commitment to obedient trust (Marshall 1978:220). The natural response after a person has come to genuine faith that Jesus is the Son of God, is to connect one's

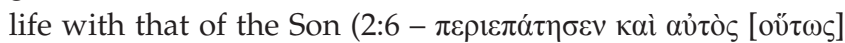
$\pi \varepsilon \rho ı \pi \alpha \varepsilon i v$ [to walk just as he walked] - NRSV) and to experience the resurrected Christ. Such obedience shows outward evidence of having true fellowship with God. The

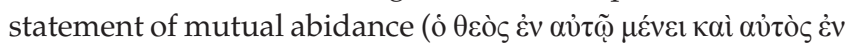
$\tau \tilde{\omega} \theta \varepsilon \tilde{\omega})^{18}$ indicates 'vital, intimate, continuous, and growing reality’ (Akin 2001:184).

When people, in the time of Jesus, encountered him physically or later through the hearing of the Gospel (cf. 4:14, 15) and consequently perceive not only the otherness and identity of this person, ${ }^{19}$ but also perceive him as God's embodiment, a new and different lived faith experience emerged. In this case Christian spirituality is the encounter of God's love in the acknowledgement of Jesus as Revealer and Saviour (Collins 2000:13; Van der Merwe 2013:4). This statement then takes us to the next point.

\section{Relational experiences of God's love - familia Dei}

The household vocabulary in 1 John refers to another configuration of the spirituality of God's love. Here God is

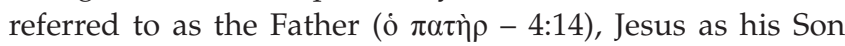

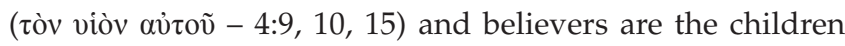

16.For Scholer (1990:311) the command to love one another relates to the theological assertion that 'no one has ever seen God' $(4: 12 ; 20)$. This reflects a Jewish basic perception of ' God's character and transcendence. This statement, to which the Gospel of John also refers (1:18, 5:37), probably reflects Moses experience as described in Exodus 33.20-23. For John (and consequently 1 John), this transcendence occurred in Jesus Christ, who 'explained' God (1:18) to such an extent that Jesus could say to his disciples: 'The one who has seen me has seen the Father' (14:9)

17.Schwöbel (1998:310) distinguishes between an external mode and relational mode of knowing. According to the external mode of knowing God's reality is not accessible ('God has never been seen'). According to the relational mode of knowing God becomes accessible. This spiritual mode of knowing, facilitates a new way of seeing ('And we have seen and testify that the Father has sent his Son to be the Savior of the world' $-4 \cdot 14)$. Here seeing is further developed by the notion of witnessing. Although the readers cannot see the incarnation the notion of witnessing. Although the readers cannot see the incarnation of the Son of God, they can see Jesus who has to be recognised as the Son ('If anyone acknowledges that Jesus is the Son of God, God lives in him and he in
God' $-4: 15$ ).

18.The verb $\mu \varepsilon \dot{v \varepsilon}$ is in the present tense.

19.Only Son, his Son, Son of God, Son, Saviour and Jesus. 
of God. ${ }^{20}$ In this pericope they are referred to as 'brothers' ( $\dot{\alpha} \delta \varepsilon \lambda \varphi$ oi $-4: 20 \mathrm{ff}$.). The Elder also states that they are 'born of

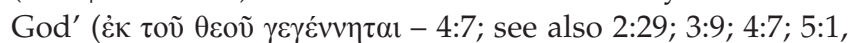
4,18 ). The Spirit is referred to as 'his Spirit' ( $\tau$ oṽ $\pi v \varepsilon v ́ \mu \alpha \tau o \varsigma$

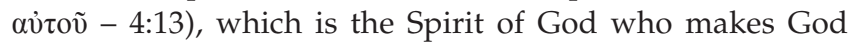
present in the household (cf. 3:24; 4:13). The Elder brings the Father, the Son, God's Spirit and 'everyone born of God' (a reference to God's children) together as a household God's household. In this household the Father's character determines the ethics: love, righteousness, purity, truth, living in the light (see Van der Merwe 2006:539) which became lived experiences within the divine household. Believers have to be born into this family of God and consequently take on the same 'love' (life) as the Father. Both these events (birth and love) create different spiritualties. Therefore, believers should not harm the fellowship in the family. It is in this environment where the children of God should love one another. In their love for one another the spirituality of God's love, actually the presence and reality of God, will be experienced (cf. Van der Watt 1999:491-511; Johnson 1993:18ff.; also Brown 1982:79ff.; Van der Merwe 2006:541). The experience of God's love is then experienced by both the one who shows love and the one who receives love.

The Elder states that God loves His children; now they are challenged to love one another (4:7). The life and love of the Father (also the Son) becomes evident and experienced in the mutual love of the community and their faith (McPolin 1978:29). Besides this pericope (see 4:7, 12), the reflexive statement, 'let us love one another' ( $\dot{\alpha} \gamma \alpha \pi \tilde{\omega} \mu \varepsilon v \dot{\alpha} \lambda \lambda \dot{\eta} \lambda$ ov $)$, occurs two more times in 1 John. It occurs first in 2:7-11 where it designates the one who is walking in the light. Secondly it occurs in 3:11-18. Here it 'is mentioned as evidence that one is a child of God' (Atkin 2001:177). In the third occurrence in $4: 7$, the Elder exhorts his readers to love one another and immediately provides a reason for them to do so, for love originates in God. Thus, when believers love one another they should reflexively experience, through this existential act of love, the love of God - whether it is a clarification towards one another, an attitude or an act (Kruse 2000:157). In the last occurrence in 4:12 the exhortation 'to love one another' constitutes the proof that God lives in that person and that God's love has become perfect.

In the text the Elder addresses his readers as 'beloved' (4:7, 11 - A $\gamma \alpha \pi \eta \tau o i ́)$. According to Kruse (2000:156) this expresses something of his affection for them and introduces a matter where he wants their special attention. This happens also in $2: 7 ; 3: 2,21 ; 4: 1$. In $4: 7$ all three Greek words of the phrase

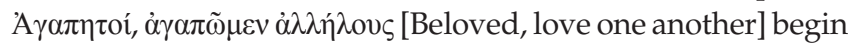
with the same letter. The readers would have recognised this alliteration. This would have drawn attention and emphasised the importance of the command (Thomas 2004:215).

Adams (1983:56) argues that naturalistic metaphors have normally some kind of an impact upon people. The Elder

20.No references of believers as "children of God" occur in this pericope, although elsewhere in the epistle. uses family metaphors in the pericope (4:7-21). This consequently implies that the relational image of the household will have an impact on the children of God. He uses selected words, analogies and comparisons that denote or connote familial bonds among the readers. The use of familial images in written documents can be effective to evoke related actions, attitudes and emotions about the divine (the Father and his Son). The use of familial terms enables the Elder to involve familiar 'personal cognitive and emotional attachments' that existed in the early Mediterranean family life. These terms he applied within the

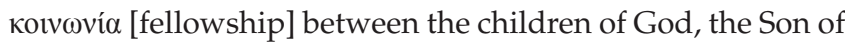
God and the Father. 'These expectations are stored in the archetypal relational pattern as it has been played out through centuries of human situations' (Adams 1983:56; also Van der Merwe 2013:5).

This convinces the strong rhetorical dynamic of the family metaphor used with regard to spirituality. Its application in particular situations to a certain group of people generates bonding and experiential powers. These powers then unite these people into a coherent group where the love of God is experienced. This lived experience of God's love is further defined by the Elder as fellowship (Van der Merwe 2013:5). Thus, seeing God and experiencing God now is possible 'if we love one another'!

\section{Mystical experiences of God's love}

The last configuration of the spirituality of God's love occurs in the mystical references that occur in the text. Early Christian mysticism did not exist or was not practiced during the first two centuries of Christianity. Louth (2007:52) clearly and convincingly points out that Christian mysticism originated with Origin (185-254). ${ }^{21}$ Although in the New Testament there are texts that have been pointed out as mystic texts such as 1 Corinthians 13:12; John 3:2; Galatians 2:20. ${ }^{22}$ There are also publications referring to the mysticism of Paul and John. ${ }^{23}$ Mystic formulas such as

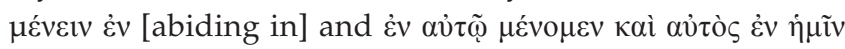
[we in him and he in us] occur in the corpus Johanneum and

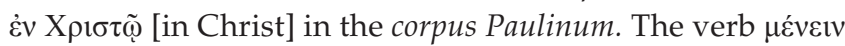
occurs quite frequently throughout the first Epistle of John as well as the Gospel. Jones (2010:179) calls $\mu$ ćveıv \&́v [abiding in] a mystical metaphor and therefore the formulation of this sub-heading: 'Mystical experiences of God's love'. The innermost experience of God is the longing to be one with him. 
The first reference in this pericope to immanence ${ }^{24}$ occurs in $4: 7$, 'Beloved, let us love one another, because love is from God; everyone who loves is born of God and knows ${ }^{25}$ God.' It is clear from the text that this immanence is connected with mutual love. Smalley (1989:237) points out that 4:7 implies that when believers love ${ }^{26}$ one another, it suggests two things: they are born of God and they know God. This statement of the Elder prepares the reader for his immanent statements in 4:12, 13, 15 and 16 ('God lives in us and we in Him'). Those born of God $(2: 29 ; 3: 9 ; 5: 1)$ have become part of the household of God. The reference that they 'know God' reflects a lived relationship - they know $^{27}$ God through their relationship with him. Such a relationship is required or is a prerequisite for a mystical experience of God's love. Believers express their love to others in the household by doing to them what they wish others would do for them (Kistemaker \& Hendriksen 2001:331).

When the Elder introduces the need for mutual love in this text (see also 4:11,12), he introduces a fresh idea by describing the fundamental basis of Johannine mysticism. It is not only, as he mentioned earlier, that love is a command of Jesus (2:711; 3:23; cf. also Jn 13) and evidence of living in the light of life (2:10; 3:11-18). The Elder introduces a new statement. The demand for love is grounded in the nature and being of God whom the Elder twice refers to be love Himself (cf. 4:8, 16). The declaration of the Elder that love 'comes from God' (i்

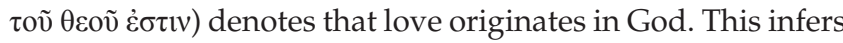
that love belongs to the divine stratum (cf. Marshall 1978:211, footnote 2). In this verse (4:7) this implication is predominant (also Eph 3:14-15; Smalley 1989:237; cf. Westcott 1902:147). God is the source of all love (4:19). Later in this pericope the Elder describes how love has been expressed and intimately experienced $(4: 9,10,12,14){ }^{28}$

The second reference to immanence appears in 4:12, 'if we love

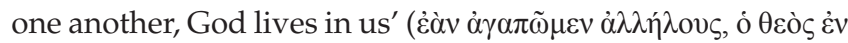
$\dot{\eta} \mu \tilde{v} v \mu \varepsilon \dot{v \varepsilon 1)}$. Again there is reference to mutual love - 'love one another'. John expresses the invisibility of God to communicate the accessibility of God, because God has revealed himself (the only Son, who is at the Father's side has made him known - 1:18b). In 4:12 the Elder states that 'no one has ever seen God'. Although, a relationship with him and mystical experience of him is viable 'if $(\dot{\varepsilon} \alpha \grave{v})^{29}$ we love

24.See Schnackenburg (1992:63-69), Lieu (1991:31-48) and Strecker (1996:44) for discussions on immanence references in $1 \mathrm{John}$.

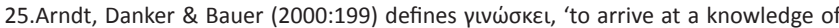
someone or something, know, know about, make acquaintance of.

26.According to Smalley $(1989: 237)$ 'the present subjunctive $\dot{\alpha} \gamma \alpha \pi \tilde{\omega} \mu \varepsilon v$ indicates that the demand for love is continuous'.

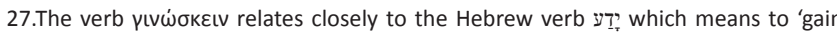
knowledge of, learn of or about' (Brown, Driver \& Briggs 1977:393) through a relationship.

28.In 3:23 the Elder links the command to love directly to the demand for faith. In that context love is mentioned after the obligation to 'believe' in Jesus Christ. Love is presented as the effect of new birth from God and the knowledge of God rather as their cause (Brooke 1912:118; cf. Marshall 1978:211-12; also Smalley 1989:238).

29.This experience is expressed in 1 John as, 'if we love one another, God lives in us' $(4: 12$ - NRSV), 'God abides in those who confess that Jesus is the Son of God, and they abide in God' (4:15 - NRSV). In both of these texts a condition (Éòv) is expressed. Only when believers 'love' one another or 'confess' Jesus as the Son of God, God will abide in them. one another'. As Jesus by his love reveals the love of the Father, similarly the children of God, 'by their mutual love, manifest to others the love of the God who dwells in them' (cf. Smalley 1989:247 who refers to Malatesta 1978:300, footnote 13). 1 John 3:18 exhorts the readers, 'Little children, let us not love in word or speech but in deed and in truth.' Then mysticism remains not only an internal activity, but also an empirical activity and experience.

The most inner expression of 'love' is to give oneself for the benefit of others. In 3:16 the Elder states, 'We know love by this, that he laid down his life for us - and we ought to lay down our lives for one another' (NRSV). ${ }^{30}$ Therefore, believers, metaphorically speaking, have to lay down their lives to help others in need. Through love, God becomes visible and embodied (3:16; also Jn 3:16). As God is, so are his children to be in this world. In such an act of love will also those who show love (laying down their lives for other), have a 'lived experience' of God's love.

In his references about 'Born of God' and 'knowing God' (4:7) and 'God lives in us' (4:12) the Elder prepares the reader for the culmination of the mystical experience statements (mystical union?) in 4:13,15,16. We find a development in the Elder's thoughts moving from the statement in 4:7 that 'love is grounded in the nature and being of God' to the reference that the prerequisite to 'love one another' is necessary (4:12) for mystical union as referred to in $4: 13,15,16$.

The third references $(4: 13,15,16)$ to immanence occurs in the formulas depicting mysticism. Due to its relatedness to Paul's $\dot{\varepsilon} v$ X to Johannine mysticism. Different from Paul's formula of immanence the Johannine formule consists also of reflexive or reciprocal formulas of immanence. The following three phrases reflect the occurrence of this mystical formula in the pericope under discussion. Note that in verses 13 and 15 the verb $\mu \varepsilon \dot{v \varepsilon ı v}$ is implied for a second time: ${ }^{31}$

${ }^{13}$ By this we know that we abide in him and he in us, because he has given us of his Spirit.

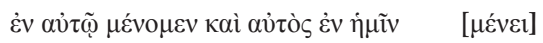

${ }^{15}$ God abides in him who confess that Jesus is the Son of God, and he abides in God.

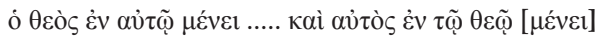

${ }^{16}$... he who abides in love abides in God, and God abides in him.

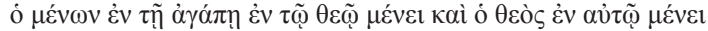

According to these three texts $(4: 13,15,16)$ the mystical immanence of God in the believer is constituted via the Spirit, confession and love. ${ }^{32}$ In the previous two references

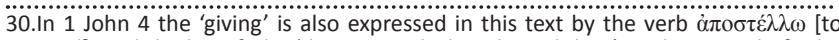
send], and the benefit by 'that we might live through him'. In the Gospel of John the Evangelist uses the verb to give ( $\delta i \delta \omega \mu \mathrm{l}-3: 16)$ to express the same idea.

31.This formula of immanence occurs throughout the Epistle: 'we abide in him and he in us' $(3: 24 ; 4: 13,15,16$; see also $2: 14,24 ; 3: 9)$.

32. Rensberger (2006:285) also relates 'confession' with 'love'. For him God 'abides in those who confess Jesus as the Son of God and love one another. Christological confession and mutual love are thus twin responses to God's prior act of sacrificial love for humankind'. 
$(4: 7,12)$ of God's immanence the focus point in both was love. In these three mystical formula the focus is again on love $\mathrm{e}^{33}$ with references to the Spirit and confession having complimentary functions to experience God's immanent love. ${ }^{34}$ The Elder takes this argument further in adding these two new perspectives (Spirit and confession). Where love constitutes the mystical union, the Spirit enables this

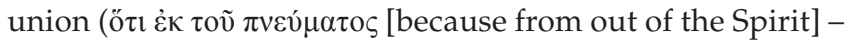
4:13) and the confession that 'Jesus is the Son of God' (If anyone acknowledges that Jesus is the Son of God, God lives in him and he in God) reflects the acknowledgement or acceptance of God's love. According to the Elder 'God

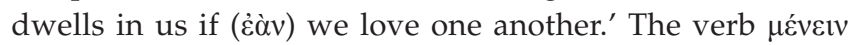
[abide] in the Gospel as well as in 1 John 'suggests an intimate and ongoing relationship between God in Christ and the believers (cf. 15:1-10)' (Smalley 1989:247; also Westcott 1902:174-75). ${ }^{35}$ In all three texts $(4: 13,15,16)$ the

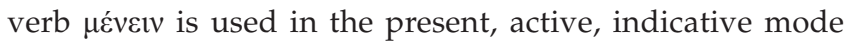
( $\mu \varepsilon \varepsilon v \varepsilon 1)$ and once in 4:16 also as a present, active, participle $(\mu \varepsilon \dot{v} \omega v) .{ }^{36}$ Where the present tense functions here to indicate continuity, the participle, in this pericope (4:7-22), refers to a particular way of life. The love of God to whom Christian believers is united transforms the believers. They will change completely and their personalities will radiate the beauty of God's love' (Harvey 1978:411). Such love constitutes a mystical experience of union with God in the life of the one who shows love. It creates an emptiness of the self and a fullness of God's love. These texts describe the praxis of mystical experience.

The contemplation (religious meditation) of the presence of God and mystical union that occur in these texts are verified in the phrase 'his love is made complete in us' $(4: 12,18)$. This happens or occurs when believers love one another. The verb ( $\tau \varepsilon \tau \varepsilon \lambda \varepsilon i \omega \mu \varepsilon \dot{v} \eta^{37}$ - passive participle) in both texts is used here emphatically to refer to an on-going fulfilment with God's involvement. In combination with 'love' it means that when there is mutual love in the Christian community it reflects the pure love coming from God in the community to reach fulfilment. To love in such a way implies that God lives in us.

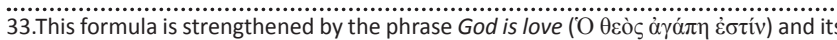
connotation with the previous two references to immanence $(4: 7,12)$.

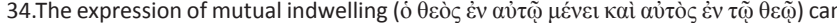
also refer to a personal relationship which is the heart of Christian living. It relates closely with keeping the word or message of Jesus (cf. McPolin 1978:35). To agree

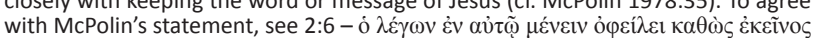

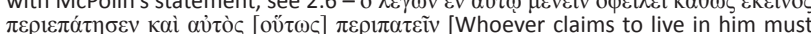
walk as Jesus did] - New International Version (NIV).

35.Bass (2007:305) points out how the verb $\mu \varepsilon \dot{v \varepsilon \varepsilon v ~ h a s ~ b e e n ~ i n t e r p r e t e d ~ i n ~ t h r e e ~}$ English Bible translations. In the Gospel of John the New American Standard Bible (NAS) translates $\mu \varepsilon \dot{v} \omega$ as 'remain', 'stay,' 'abide,' 'endure,' 'continue,' and 'live.' The NRSV translates it 'remain,' 'stay,' 'endure,' 'abide,' 'continue,' 'have a permanent place,' 'dwell with,' 'last,' 'left,' and 'live.' The English Standard Version (ESV) translates it 'remain,' 'stay,' 'abide,' 'endure,' 'dwell with,' and 'continue.'

36.When their love becomes sacrificial love, it is then when believers empty themselves. In their emptiness they then become one or united with the divine. True believers are those 'in whom Love expresses itself, incarnates itself, and unfolds itself in a visible, tangible way through all the dimensions of human life' (Harvey 1978:411). Such believers are willing to sacrifice themselves for the sake of others.

37.'The first is found in 2:5, where completeness of love for God is expressed in 7. The first is found in 2:5, where completeness of love for God is expressed in they love one another.' More references are found in 4:17, 18, where God's love is said to have completed its work in believers when they can face the Judgement Day without fear (Kruse 2000:162)
This thought is elaborated in 4:13-16 and that his love has been brought to completion in the believers (4:15ff.). ${ }^{38}$ This completion reflects a mystical union and intensity.

\section{Conclusion}

In the pericope 4:7-22, a dichotomy between the invisibility and visibility of God occurs to constitute an existential tension. Two apophatic statements about God's invisibility appear as well as two kataphatic statements that 'God is love'. In a tactical way the Elder describes how God can become visible and experienced. This is possible through the 'lived experiences' of God's imminent love in the incarnation of his Son and in the mutual love between believers. This article focussed on three aspects of the 'spirituality of love' that lies embedded in the text (4:7-22):

- faith lived experiences of God's love: God has sent his Son to reveal himself in his love and to bring salvation. The acceptance of this in faith creates a certain spirituality of God's love;

- relational lived experiences of God's love: God's love is experienced when believers in the familia Dei love one another. Both the one who loves and the one who is loved should experience the love and reality of God; and finally

- mystical lived experiences of God's love: The culmination point of the mystical experience of God's imminent love is expressed by the Elder as the reciprocal indwelling of God and believers when they love one another. The love of God will always evoke a misterium tremendum. Both the apophatic and kataphatic paradigms should challenge those who are seriously interested in a mysticism of purifying, illuminating and transforming love to examine and practice more carefully what can be found in Christianity's own mystical tradition (Harvey 1978:426) so that the lived faith experience of God-with-us will also become God-in-us.

\section{Acknowledgements Competing interests}

The author declares that he has no financial or personal relationships which may have inappropriately influenced him in writing this article.

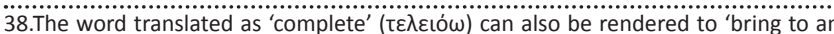
end, finish, accomplish' (Arndt et al. 2000:996). These renderings seem to indicate a condition in which there is an elimination of inadequacies. A more appropriate understanding would be that of achieving a goal, namely the practice of believers loving one another (cf. Hiebert 1990:78). According to Brown (1982:521) 'God abides in us and the love that comes from Him reaches perfection in our love for others' 'One's love for other believers will demonstrate the fact that one is indwe by God (Akin 2001:182).

In 4:17, 18 the Elder adds a new perspective connected to 'complete love': the theme of judgement. He refers to what he has just written. He informs the reader that the love one has for God has an effect on the future of that person. Both, the confession of Jesus as Lord and the mutual abiding between God and the believer conction God's love to have its full manifestation (cf. Hien God and the believe sanction God's love to have its full manifestation (cf. Hiebert 1990:184). Thus, a believer's close union with God (the mutual abidance) makes that believer's love is complete or perfected. The consequence is that the manifestation and lived Judgement Day. (Akin 2001:185).

In verse 4:18 the Elder elaborates on what he has already stated in verse 4:17. He verifies why the believer needs not to fear. For him the relationship between the believer and God through Christ is based on love. In love 'there is no fear'. The claim here is that love and fear are mutually exclusive. A severe disparity exists between the two. Only one can exist, because perfect love 'drives out fear'. All fear is abolished from those in whom God's love is being perfected. In conclusion: where there is perfected love, God can be seen and experienced and is there no where there is perfected (cf. Akin 2001:186). 


\section{References}

Adams, J., 1983, 'The familial image in rhetoric', Communication Quarterly 31(1), 56 61, viewed 18 March 2016, from http://dx.doi.org/10.1080/01463378309369486

Akin, D.L., 2001, 1, 2, 3 John, Broadman \& Holman Publishers, Nashville. Logos Bible Software.

Arndt, W., Danker, F.W. \& Bauer, W., 2000, A Greek-English lexicon of the New Testament and other early Christian literature, 3rd edn. (BDAG), Chicago University Press, Chicago.

Bass, C.D., 2007, 'A Johannine perspective of the human responsibility to persevere in the faith through the use of meno and other related motifs', Westminster Theological Journal 69, 305-325.

Brooke, A.E., 1912, A critical and exegetical commentary on the Johannine epistles, T\&T Clark, Edinburgh.

Brown, R.E., 1982, The epistles of John, Doubleday, Garden City.

Brown, F., Driver, S.R. \& Briggs, C.A., 1977, Enhanced Brown-Driver-Briggs Hebrew and English Lexicon, Clarendon Press, Oxford.

Collins, K.J. (ed.), 2000, Exploring Christian spirituality, Baker Books, Grand Rapids.

Dodd, C.H., 1946, The Johannine Epistles, MNTC, Hodder \& Stoughton, London.

Harvey, D.E., 1978, 'Christian Apophatic and Kataphatic Mysticisms', Theological Studies 39, 399-426.

Hiebert, D.E., 1988, 'An exposition of 1 John 1:1-4', Bibliotheca Sacra 145, 197-210.

Hiebert, D.E., 1990, 'An expositional study of 1 John. An exposition of 4:7-21' Bibliotheca Sacra 147(585), 69-88.

Johnson, T.F., 1993, 1, 2, and 3 John, Hendrickson, Peabody,

Jones, P.R., 2010, 'A Presiding metaphor in first John', Perspectives in Religious Studies 37(2), 179-193.

Kabbalah - Jewish Mysticis I, nd., 'What is Kabbalah and The Prerequisites for its Study', viewed 24 April 2016, from http://www.morashasyllabus.com/class/ Kabbalah\%20Jewish\%20Mysticism\%20l.pdf

Kistemaker, S.J. \& Hendriksen, W., 2001, Exposition of James and the Epistles of John, Baker Book House, Grand Rapids.

Kruse, C.G., 2000, The letters of John, Eerdmans, Grand Rapids.

Lieu, J., 1991, The theology of the Johannine epistles, Cambridge University Press, Cambridge.

Louth, A., 2007, The Origins of the Christian Mystical Tradition: From Plato to Denys, Oxford University Press, Oxford, viewed 24 April 2016, from http://ixoyc.net/ data/Fathers/525.pdf

Malatesta, E., 1978, Interiority and Covenant, Biblical Institute Press, Rome.

Marshall, I.H., 1978, Epistles of John, Eerdmans, Grand Rapids.
McPolin, J., 1978, Johannine mysticism, The Way 18, 25-35, viewed 15 March 2016 from http://www.theway.org.uk/Back/18McPolin.pdf

Painter, J., 2002, 1, 2, and 3 John, The Liturgical Press, Collegeville.

Rensberger, D., 2006, 'Conflict and community in the Johannine letters', Interpretation July, 278-291.

Schnackenburg, R., 1992, The Johannine epistles: introduction and commentary, Crossroad, New York.

Schneiders, S.M., 2000, 'Spirituality in the academy', in K.J. Collins (ed.), Exploring Christian spirituality. An ecumenical reader, pp. 249-269, Baker Books, Grand Rapids.

Scholer, D.M., 1990, '1 John 4:7-21', Review \& Expositor 87(2), 309-314.

Schwöbel, C., 1998, 'God is love: the model of love and the trinity', Neue Zeitschrift für systematische Theologie und Religionsphilosophie 40(3), 307-328.

Sheldrake, P., 2000, 'What is Spirituality?', in K.J. Collins (ed.), Exploring Christian Spirituality, pp. 21-42, Baker Books, Grand Rapids.

Smalley, S.S., 1989, 1, 2, 3 John, Word, Incorporated, Dallas. Logos Bible Software.

Strecker, G., 1996, The Johannine letters: a commentary on 1, 2, and 3 John, Fortress Press, Minneapolis.

Thomas, J.C., 2004, A Pentecostal commentary on 1 John, 2 John, 3 John, The Pilgrim Press, Cleveland

Van der Merwe, D.G., 2005, 'Salvation in the Johannine epistles', in J. van der Watt (ed.), Salvation in the New Testament. Perspectives on Soteriology, pp. 437-464, Brill, Leiden.

Van der Merwe, D.G., 2006, "'A matter of having fellowship": Ethics in the Johannine epistles', in J. van der Watt (ed.), Identity, ethics, and ethos in the New Testament, pp. 535-563, Walter de Gruyter, Berlin.

Van der Merwe, D.G., 2013, 'Early Christian spirituality according to the First Epistle of John: the identification of different "lived experiences"', HTS Teologiese Studies/ Theological Studies 69(1), Art. \#1286, 9 pages. http://dx.doi.org/10.4102/hts. v69i1.1286

Van der Merwe, D.G., 2015, "Early Christian spirituality of "seeing the divine" in 1 John', HTS Teologiese Studies/Theological Studies 71(1), Art. \#2790, 11 pages. $\mathrm{http}: / / \mathrm{dx}$.doi.org/10.4102/hts.v71i1.2790

Van der Watt, J.G., 1999, 'Ethics in first John: a literary and socioscientific perspective', Catholic Biblical Quarterly 61, 491-511.

Waaijman, K., 2002, Spirituality: forms, foundations, methods, transl. J. Vriend, Peeters, Dudley.

Westcott, B.F. (ed.), 1902, The Epistles of St. John: the Greek text with notes and essays, 4th edn., Macmillan, London.

Wigner, D.E., 2007, 'Clarity in the Midst of Confusion: Defining Mysticism', Perspectives in Religious Studies 34(3), 331-335. 